\title{
Spatial modelling of urban heat islands and its planning implications in Obio/Akpor local government area
}

\begin{abstract}
Urban Heat Island (UHI) has become a global recurring phenomenon in most urban centres. Obio/Akpor Local Government Area has had a fair share of this phenomenon owing to its thriving trend in both planned and unplanned urbanisations. The study looks at the impact of UHI in selected communities in Obio/Akpor Local Government in five epochs of 2000, 2005, 2010, 2015 and 2020. Parts of the objectives include identifying the UHI in these communities in the Local Government Area, modelling of UHI in selected communities in Obio/Akpor Local Government Area and determining the trend in UHI using Epoch data of Urban Surface Temperature from LANDSAT thermal imageries Figure 1.

The study adopted Thermal Infrared Remote (TIR) Sensing and Geospatial Information System (GIS) Techniques using LANDSAT TM, LANDSAT ETM and LANDSAT OLI sensors to acquire Urban Surface temperature data emitted by objects in the study area and store the information as a digital number (DN) thermal band (B6, B61 and B10) as well as secondary data acquired from the Nigerian Meteorological Agency (NIMET). Urban Surface Temperature was obtained through the following processes: Acquisition of Urban Surface Temperature value of the study area in form of DN, the conversion of $\mathrm{DN}$ to Spectral radiance using the Spectral radiance equation. The data were processed, analysed, and modelled using ESRI's ArcGIS 10.1. The results revealed that in 2000, the Average Urban Temperature of the study area was $23.480^{\circ} \mathrm{C}$, the value increase to $27.647^{\circ} \mathrm{C}$ in 2005 with a difference of $4.167^{\circ} \mathrm{C}$. The temperature of 2005 increased to $31.598^{\circ} \mathrm{C}$ in 2010 with a difference in temperature of $3.951^{\circ} \mathrm{C}$. Accordingly, the temperature of 2010 increased to $33.054^{\circ} \mathrm{C}$ in 2015 with a temperature difference of $1.456^{\circ} \mathrm{C}$ and temperature of 2015 increased to $33.070^{\circ} \mathrm{C}$ with a difference of $0.016^{\circ} \mathrm{C}$. The analysis shows an increasing trend of $40 \%$ in the Urban Surface Temperature in the study area in the various years under investigation. The study recommends that development should be extended to other Local Government Areas in the state to reduce rural-urban migration to Obio/Akpor Local Government. Tree planting should be encouraged as a way of mitigating the effect of air pollution, heatwaves and harmful gases emitted into the environment by combust engines and gas flaring, the use of combustion engines be replaced by electric cars to reduce the level of carbon dioxide $\left(\mathrm{CO}_{2}\right)$ emitted ti environment. Policymakers to restrict unplanned urban growth and to increase tree planting in the built-up areas.
\end{abstract}

Keywords: spatial modelling, thermal infrared, planning, urban heat island and urbanisation
Volume 5 Issue 5 - 202 I

\author{
Lawson Nwidum,' Kurotamuno Peace \\ Jackson,' Ibama Brown² \\ 'Department of Surveying and Geomatics, Rivers State \\ University \\ ${ }^{2}$ Department of Urban and Regional Planning, Rivers State \\ University, Port Harcourt, Nigeria
}

Correspondence: Ibama Brown, Department of Urban and Regional Planning, Rivers State University, Port Harcourt, Nigeria, Email brown.ibama@ust.edu.ng

Received:September 08, 202I | Published: September 30, 2021

\section{Introduction}

In the last two decades, there has been a spike in research related to changes in land cover, urban ecology, urbanisation, and socioeconomic impacts leading to changes in the global environment. One of such identified changes in the global environment is an increase in the near-surface temperatures occasioned by rapid urbanisation with a universal identity as the Urban Heat Island (UHI). ${ }^{1}$ Luke Howard in 1810 studied the phenomenon of UHI in an area of land that experiences consistent surges in surface temperature more than adjoining areas. ${ }^{2}$

As of 2018, trends in global migration indicate a bias for urban areas because in a relatively short time, and the urban-based global population had surpassed $50 \%$ and it is expected to peak at $68 \%$ by 2050 United Nations report. ${ }^{3}$ Thus, the challenges and effects associated with UHI is phenomenal and should be regarded as a global challenge that has the capacity of impacting negatively on the habitability and smooth running of urban environments. ${ }^{4}$ The impact of UHI is felt across every sphere of human endeavour especially in urban planning, health, comfort, energy management, and urban air pollution.

The occurrence of UHI increases peak energy demand and energy consumption evident in increased energy demand for cooling systems which indicates a $0.6^{\circ} \mathrm{C}$ increase in the ambient air temperatures, electricity requirement for cooling increases by $1.5-2 \%$ at temperatures higher than $20^{\circ} \mathrm{C}$ implying that $5-10 \%$ of the municipal demand for electricity goes into UHI compensation. ${ }^{5}$

Some other possible impacts of UHI include surges in air pollutants and greenhouse gases emissions, thermal pollution in the aquatic systems, discomfort, health risks, and local climate alterations such as wind and rainfall patterns, humidity, fog formation and impaired water quality. ${ }^{6}$

In recent times, the spike in the formation of UHI and its attendant challenges such as air pollution, heatwave, greenhouse effect and increased energy consumption has been a source of concern 
to researchers. ${ }^{7}$ The entire Obio/Akpor local government area of Rivers State is vulnerable to the vagaries of UHI considering its cosmopolitan nature. Since incidences of UHI have enormously affected air conditioning loads, worsened air and water quality and exacerbated heatwaves as well as irregular weather patterns which have also affected the economic base of residents as they now spend more on energy, health, and cooling systems.

The enormity of the challenges engendered by the emergence of UHI necessitates the spatial modelling of Urban Heat Island (UHI) in Obio/Akpor Local Government Area of Rivers State, using Thermal Infrared Remote (TIR) Sensing and Geospatial Information System (GIS) Techniques to monitor and model the sections of Urban Heat Island UHI. Therefore, this study employs satellite thermal infrared remote sensing and Geospatial Information System (GIS) techniques to monitor and model the UHI of Obio/Akpor Local Government Area of Rivers State, Nigeria through the acquisition of LANDSAT imagery to measure and analyse the Urban Surface Temperature of the study area.

To achieve this, this study would be able to determine Urban Heat Island (UHI) on various Land Use and Land Cover (LU/LC) in the study area. To Model Urban Heat Island in the different Land use and Land Cover types in Obio/Akpor Local Government Area of Rivers State. To determine the trend in Urban Heat Island in Obio/Akpor using Epoch data of Urban Surface temperature measurement from LANDSAT thermal imageries.

\section{Study area}

Obio/Akpor Local Government Area falls within the Metropolitan region of Port Harcourt, the oil and gas hub of Nigeria, one of the major cities of the Niger Delta located in Rivers State. The Local Government Area covers an approximate area of $260 \mathrm{~km}^{2}$ with a population of 464,789. ${ }^{8}$ Obio/Akpor is bounded in the South by Port Harcourt City Local Government area, Oyigbo and Eleme to the East, Etche and Ikwerre to the North, and Emohua to the West. It is located between Latitudes $4^{\circ} 45^{\prime} \mathrm{N}$ and $5^{\circ} 00^{\prime} \mathrm{N}$ and longitudes $6^{\circ} 50^{\prime} \mathrm{E}$ and $8^{\circ} 00^{\prime} \mathrm{E}$. The Local Government Area is a lowland area with an average elevation below $30 \mathrm{~m}$ above sea level. Significant changes in the land use/ land cover in the area include changes in water bodies, built-up areas, depletion of the mangrove vegetation along rivers and creeks shorelines, vegetation, and wetlands. The mean temperature ranges between $30.0^{\circ} \mathrm{C}-33.0^{\circ} \mathrm{C}$, while the annual rainfall ranges between $2100 \mathrm{~mm}-4600 \mathrm{~mm}$ as reported by Nigerian Meteorological Agency. ${ }^{9}$

\section{Urbanisation and urban heat island}

Urbanisation comes with phenomenal changes that affect the local surface and atmosphere. A myriad of micro and medium climates exists occasioned by changes in the thermal properties, radiation, aerodynamic properties, and humidity. An Urban Heat Island (UHI) represents an urban area that usually generates higher temperatures than its non- urbanised surroundings. The term 'Island' is culled from the shape of the temperature signature pattern and the pattern of isotherms that resembles an island. ${ }^{10}$ Usually, the intensity of this phenomenon increases as a result of city growth and its corresponding surges in population. UHI as a phenomenon is a product of urban climate change and urbanisation consequences. It represents a higher air surface temperature variation in an urban settlement due to the process of continuous urbanisation and high population growth compared to adjoining rural areas, getting global attention due to the negative impacts on the environment, vegetation, and human health. ${ }^{11,12,13}$

\section{Causes of urban heat island}

In the opinions of ${ }^{14}$ and $^{15}$, UHI emerges as a result of

(i) Absorbing long-wave radiation by urban surfaces in view of the sky and re-emitting it into the polluted atmosphere above the city causes an increase in counter radiation (back radiation).

(ii) The effect of buildings on decreasing sky view causes the reduction of Long-wave radiation loss.

(iii) The effect of canyon geometry on the albedo causes wide absorption of short-wave radiation.

(iv) Low wind speeds in the canopy (tall buildings and narrow sidewalks) negatively affect sensible heat loss.

(v) Characters of urban material cause frequent storage heat during the day which is released at night.

(vi) Anthropogenic heat sources input more heat into the urban atmosphere and surface.

(vii) Converting green areas to impervious surfaces in the cities causes a decrease in evaporation and transpiration and hence higher temperature.

\section{Factors which affect urban heat island (UHI)}

Different factors contribute to and affect Urban Heat Island as repeatedly opined by ${ }^{16,17,18}$ such as population growth, urban geometry, and the surface cover/radiative exchange. Moreover, UHI impacts the Urban dwellers in several aspects such as an increase in energy consumption, Air-quality and Green-House gases emission and Human Health and Comfort as also reported repeatedly by ${ }^{1,19,20,21}$

(i) Population: The population size of the city has a clear relationship with Temperature variation between the city and surrounding rural areas. Under transparent skies, UHI intensity is positively related to the logarithm of the population. ${ }^{16}$

(ii) Urban geometry: The temperature variations between the urban and rural areas depend on urban geometry factors (size, shape and direction of buildings and streets) and the nature of urban surfaces (albedo, heat capacity, thermal conductivity, and wetness). ${ }^{17}$

(iii) Surface cover/radiative exchange: Impervious surfaces such as asphalt and concrete absorb, store and re-radiate more heat energy than vegetated surfaces. ${ }^{18}$ For instance, the surface of a parking lot is usually hotter than nearby fields due to higher radiative forcing and greater heat storage. ${ }^{17}$

\section{Impacts of urban heat island (UHI)}

(i) Increased energy consumption: According to ${ }^{19}$ increased temperatures exacerbate energy demands in cities, which include the requirement of air conditioning to keep buildings cool. The use of air conditioners in both the residential and the commercial sector increases the UHI intensity. ${ }^{22}$

(ii) Air quality and greenhouse gases: The emission of greenhouse gases and air pollution increases as a result of rising energy demands. ${ }^{20}$ Therefore, these emissions negatively affect the physical condition of people and contribute to air troubles, including acid rain. In addition, carbon dioxide emitted from power plants that work with fossil fuels contributes to global climate changes. ${ }^{1}$ 
(iii) Human health and comfort: During the hot summer season, the UHI effect influences urban residents, reducing thermal comfort while increasing the risk of heatstroke, exhaustion, and heat-related mortality. In addition, it increases the effect of heatwaves on inhabitants who are sensitive to high temperatures, such as the elderly, children and the sick. ${ }^{21,1}$

\section{Concept of thermal infrared remote (TIR) sensing}

\section{Estimation of urban surface temperature}

Remote sensing can quantify the average temperature of a pixel of imagery to determine the urban surface temperature of the pixel. Both infrared and microwave sensors have been used to detect LST.
Infrared thermal sensors provide high spatial resolution (90 metres for ASTER). However, one fundamental limitation of this method is that they are only capable under transparent sky situations. Conversely, passive microwave sensors provide lower spatial resolution and lower precision while they are capable to use in all-weather situations because they are only slightly affected by atmospheric influences. ${ }^{22}$

\section{Methods and materials}

\section{Research design}

The study was carried out using Thermal Infrared Remote (TIR) sensing and Geographic Information System (GIS) Techniques. Figure 2 show the research methodology flow chart design.

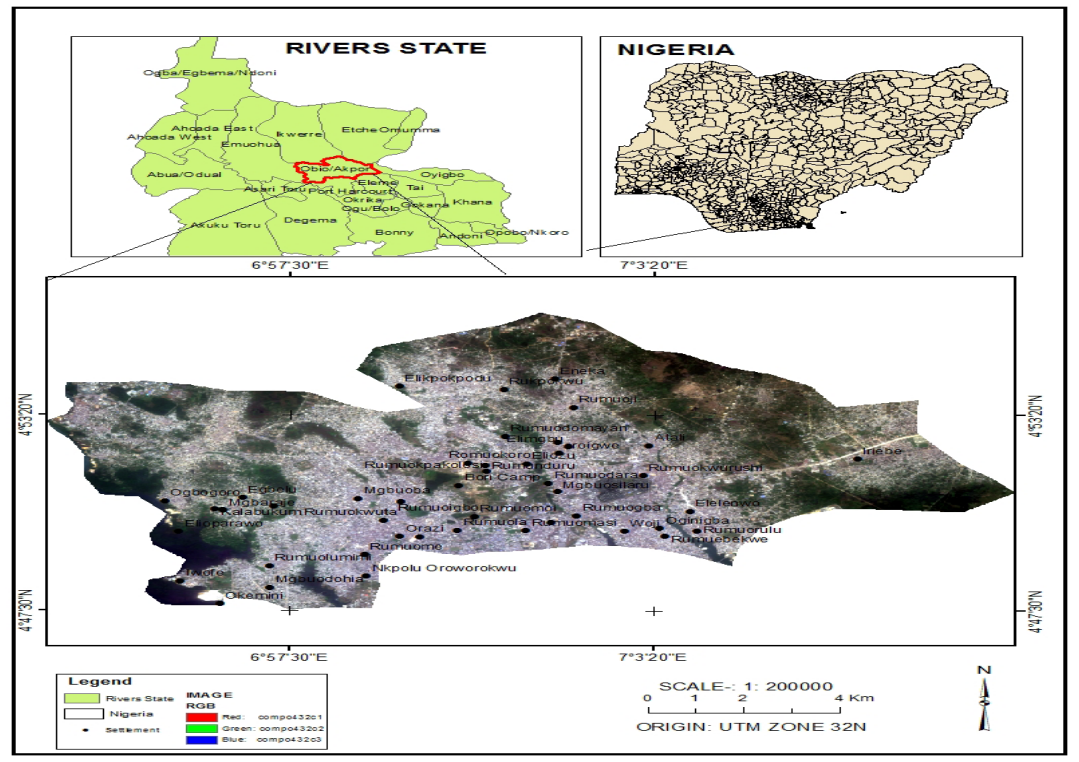

Figure I Image showing the study Area.

Source: SPOT imagery.

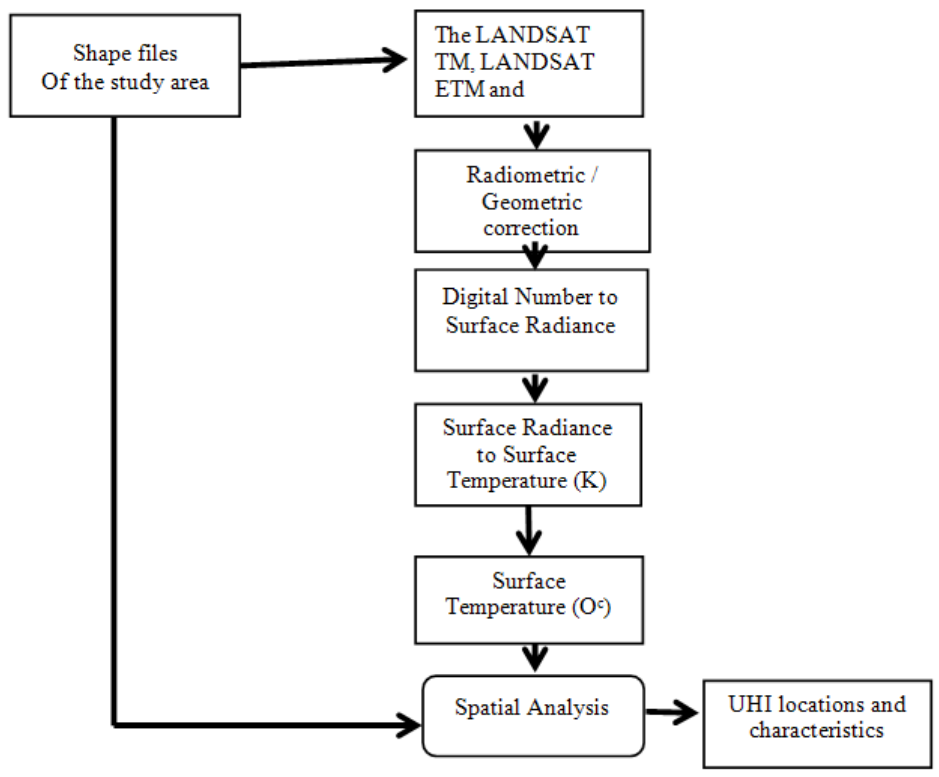

Figure 2 Flow chart of Research Design.

Source:Authors 2021.

Citation: Nwidum L, Jackson KP, Brown I. Spatial modelling of urban heat islands and its planning implications in Obio/Akpor local government area. Int J Hydro. 202I;5(5):240-250. DOI: 10.15406/ijh.2021.05.00286 
Thermal infrared remote sensing is the branch of Remote Sensing that deals with the acquisition, processing and interpretation of data acquired primarily in the thermal infrared (TIR) region of the electromagnetic (EM) spectrum. In thermal remote sensing, the radiations 'emitted' from the surface of the earth (target) are being measured, as opposed to optical remote sensing where the radiations 'reflected' by the target under consideration is measured. ${ }^{23}$

TIR sensing method was used to acquire the data of the Urban Surface Temperature of the Study area at 30 meters intervals across various land use and land cover in the study area. This method was adopted due to its relevancy of acquiring Urban Surface Temperature across various Land Use/Land Cover (LU/LC) in the study area and its capability to provide time-series data of different epochs to enable proper monitoring and modelling of the Urban Heat Island of the
Study area. The (LU/LC) identified in the study is the build-up Area, Vegetation and Water Body.

\section{Data acquisition}

The Data used for the study was obtained from the LANDSAT TM, LANDSAT ETM and LANDSAT OLI sensors that acquire Urban Surface temperature data emitted by objects in the study area and store the information as a digital number (DN) thermal band (B6, B61 and B10). LANDSAT TM images were obtained from 5 different epochs: 2000,2005,2010,2015 and 2020 respectively. See Table 1. The LANDSAT images were rectified to the UTM projection system (datum WGS84, zone $32 \mathrm{~N}$ ). The study was further enabled using ESRI ArcGIS 10.1 version 2012 for Data Acquisition, Processing, modelling and Data Analysis.

Table I Table showing Data Obtained for this Study

\begin{tabular}{llllll}
\hline Sensor & Acquisition Year & Acquisition Time & Band used & Resolution (m) & Data Source \\
\hline LANDSAT TM & 2000 & $09: 09: 43$ & B6=TIR & $30 \times 30$ & http://glovis.usgs.gov \\
LANDSAT ETM & 2005 & $09: 35: 36$ & B6I=TIR & $30 \times 30$ & http://glovis.usgs.gov \\
LANDSAT ETM & 2010 & $09: 41: 21$ & B6I=TIR & $30 \times 30$ & http://glovis.usgs.gov \\
LANDSAT OLI & 2015 & $09: 45: 04$ & BI0=TIR-I & $30 \times 30$ & http://glovis.usgs.gov \\
LANDSAT OLI & 2020 & $09: 45: 17$ & BI0=TIR-I & $30 \times 30$ & http://glovis.usgs.gov
\end{tabular}

\section{Data processing}

The data was processed by converting the DNs to radiance values using the bias and gain values specific to the individual pixel. This was closely followed by converting the radiance data to degrees in Kelvin. And finally converting the temperature in Kelvin to the temperature Celsius.

\section{Converting the digital number (DN) to spectral radiance (L $\lambda)$ :}

Radiance $(\mu \mathrm{m})$ in bands 6,61 and 10 were calculated from digital numbers (DN) using standard NASA equations. The spectral radiance $(\mathrm{L} \lambda)$ was calculated as follows

$\mathrm{L} \lambda=\frac{\mathrm{L}_{\mathrm{MAX} \lambda}-\mathrm{L}_{\mathrm{MAX} \lambda}}{\mathrm{Q}_{\mathrm{CALMAX}}-\mathrm{Q}_{\mathrm{CALMIN}}}\left(\mathrm{DN}_{\mathrm{QCALMIN}}\right)+\mathrm{L}_{\mathrm{MIN} \lambda}$

Where:

$\mathrm{L}_{\mathrm{MAX}} \lambda,=$ maximum spectral radiance for the band

$\mathrm{L}_{\mathrm{MIN}} \lambda=$ minimum spectral radiance for the band

$\mathrm{Q}_{\text {CALMAX }}=$ maximum quantize calculated for the band

$\mathrm{Q}_{\text {CALMIN }}=$ minimum quantize calculated for the band

$\mathrm{DN}=$ pixel $\mathrm{DN}$ value.

\section{Converting spectral radiance $(\mathrm{L} \lambda)$ to temperature in kelvin $(\mathrm{K})$}

The ETM+ thermal band data could be converted from spectral radiance to Temperature in Kelvin $(\mathrm{K})$ using the expression below;

$$
T=\frac{K_{2}}{\ln \left(\frac{k_{1}}{L_{\gamma}}+1\right)}
$$

Where:
$\mathrm{K}_{1}$ and $\mathrm{K}_{2}$ are constants. $\mathrm{K}_{1}$ and $\mathrm{K}_{2}$ values can be extracted from the metadata file of the downloaded thermal Image.

\section{Converting temperature from kelvin to celsius}

The temperature in Celsius was calculated using the following equation:

$$
\mathrm{T}(\mathrm{C})=\mathrm{T}-273.13
$$

Where:

$\mathrm{T}(\mathrm{C})=$ Temperature "Celsius,"

$\mathrm{T}=$ Temperature "Kelvin",

273.13 = Zero Temperature "Kelvin".

Conversion procedures for images acquired from digital number (dn) to spectral radiance-temperature kelvin-celsius

For LANDSAT 2020 OLI, TOA radiance is computed using the formula,

$$
\mathrm{L} \lambda=\mathrm{M}_{\mathrm{L}} \times \mathrm{Q}_{\mathrm{cal}}+\mathrm{A}_{\mathrm{L}}
$$

Where:

$\mathrm{L}_{\lambda}=$ spectral radiance in $\mathrm{Wm}^{-2} \mathrm{Sr}^{-1}$

$\mathrm{M}_{\mathrm{L}}=$ radiance multiplicative scaling factor for the band

$\mathrm{Q}_{\text {cal }}=\mathrm{L} 1$ pixel value in $\mathrm{DN}$ and

$\mathrm{A}_{\mathrm{L}}=$ radiance additive scaling factor for the band

Here band 10 of the 2020 LANDSAT data was used and the parameters are;

$$
\mathrm{M}_{\mathrm{L}}=0.000334
$$




$$
\mathrm{A}_{\mathrm{L}}=0.1
$$

Substituting the values in the equation to computes spectral radiance image. The surface temperature was computed from the TOA radiance images using equation (2). $\mathrm{K}_{1}$ and $\mathrm{K}_{2}$ are the thermal conversions constant for bands 6 and 10. The parameters $M_{L}, A_{L}, K_{1}$, and $\mathrm{K}_{2}$ are obtained from the LANDSAT header file. The thermal constants for the TM, ETM+ and OLI were given in Table 2.

Table 2 Thermal conversion constants for different LANDSAT Satellite sensors

\begin{tabular}{llll}
\hline BAND & SENSOR & K1 & K2 \\
\hline 6 & TM & 607.76 & 1260.56 \\
6 & ETM and ETM+ & 600.09 & 1282.71 \\
10 & OLI & 774.8853 & 1321.079 \\
\hline
\end{tabular}

From Table 2, the parameters are:

$$
\begin{aligned}
& \mathrm{K} 1=774.8853 \\
& \mathrm{~K} 2=1321.0789
\end{aligned}
$$

By substituting the values in equation (2), Urban Heat Island for band 10 in the study area was computed in the Kelvin temperature scale. The computations were done in ESRI's ArcGIS 10.1 software.

Accordingly, the computed temperature in the Kelvin scale was converted to temperature in the Celsius scale using equation (3). The Data processing interface in ESRI's ArcGIS 10.1 software application is shown in Figure $2 \& 3$.

For the LANDSAT Thematic Mapper (TM), and Enhanced Thematic Mapper Plus (ETM+), TOA radiance in $\mathrm{Wm}^{-2} \mathrm{Sr}^{-1}$, is computed using equation (1)

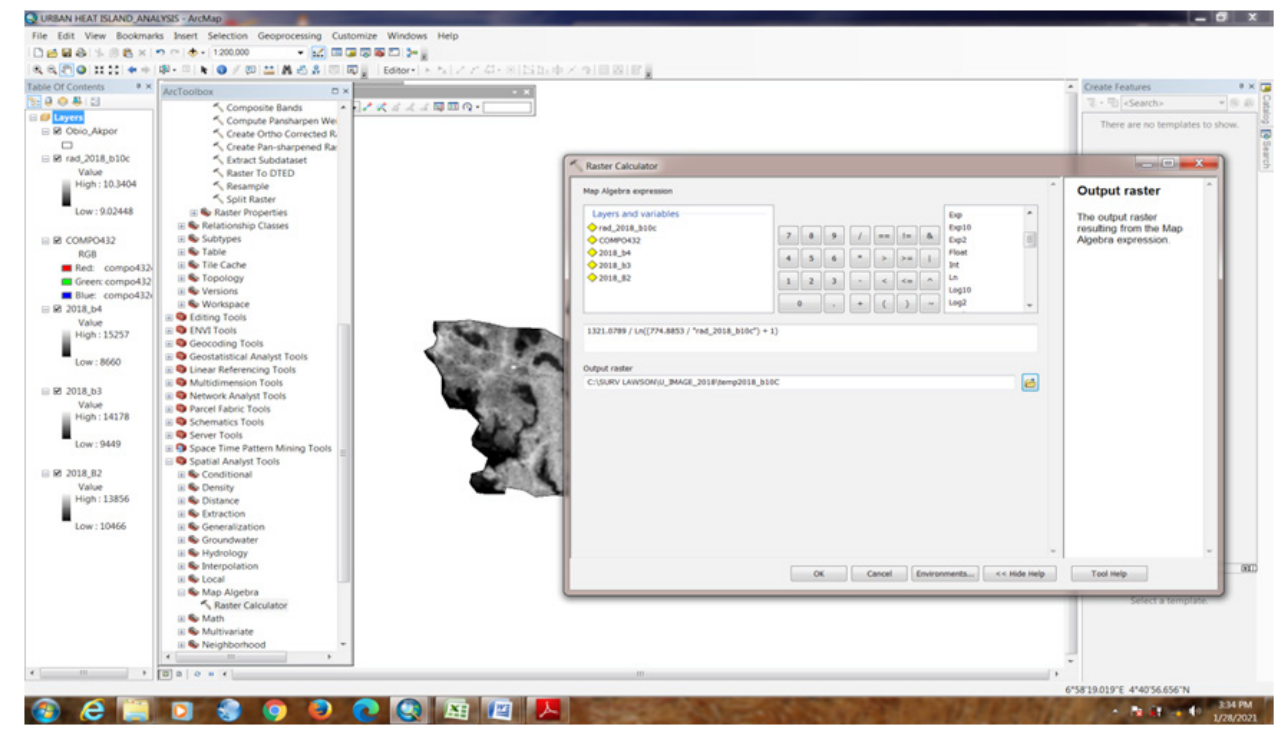

Figure 3 Screenshot of 2020 image in ESRI's ArcGIS 10.I software application. Screen Prints of 2020 image.

Computing for LANDSAT TM 2000 using band 6, the values are:

$$
L_{M A X \lambda},=15.303 ; L_{M I N \lambda}=1.238 ; Q_{C A L M A X}=255 \text { and } Q_{C A L M I N}=1
$$

By substituting the values in equation (3.1) together with the raw image data, the radiance image was computed. Now converting radiance image to brightness temperature, thermal equation (2) was introduced.

Where:

$$
\begin{aligned}
& \mathrm{K}_{1}=607.7600 \\
& \mathrm{~K}_{2}=1260.5600
\end{aligned}
$$

Converting to Temperature Celsius, equation (3.3) was introduced. Also computing for LANDSAT 2005 ETM using band 61 (thermal band), the values of the parameters are:

$$
L_{M A X \lambda},=17.04 ; L_{M I N \lambda}=0 ; Q_{C A L M A X}=255 ; \text { and } Q_{C A L M I N}=1
$$

Substituting the values in equation (1), the Digital Number (DN) is converted to radiance image. Now is to convert radiance image to brightness temperature by utilizing thermal equation (2). The thermal constants for ETM area:

$$
\begin{aligned}
& \mathrm{K}_{1}=600.0900 \\
& \mathrm{~K}_{2}=1282.7100
\end{aligned}
$$

Converting to Temperature Celsius, equation (3) was introduced. Also computing for LANDSAT 2010 ETM using band 61 (thermal band), the values of the parameters are:

$$
L_{M A X \lambda},=17.04 ; L_{M I N \lambda}=0 ; Q_{\text {CALMAX }}=255 \text { and } Q_{\text {CALMIN }}=1
$$

Substituting the values in the radiance equation (1), radiance image is derived. Now is to convert radiance image to brightness temperature by utilizing thermal equation (2). The thermal constants for ETM area:

$$
\begin{aligned}
& \mathrm{K}_{1}=600.0900 \\
& \mathrm{~K}_{2}=1282.7100
\end{aligned}
$$

Converting to Temperature Celsius, equation (3) was employed. In the same way, computing for LANDSAT 2015 OLI using band 10 (which is the sensor thermal band), the values of the parameters used are giving below:

$$
\mathrm{M}_{\mathrm{L}}=0.000334 ; \mathrm{A}_{\mathrm{L}}=0.1
$$


Substituting the values in the model equation (4) to computes spectral radiance images as described earlier. Urban Heat Island was also computed from the TOA radiance image using the formula stated earlier in equation (2).
In the model, the thermal Constance for the OLI sensor is:

$$
\begin{aligned}
& \mathrm{K}_{1}=774.8853 \\
& \mathrm{~K}_{2}=1321.0789
\end{aligned}
$$

Sample of radiance and temperature images of the study area in 2000 Figure $4 \& 5$ :

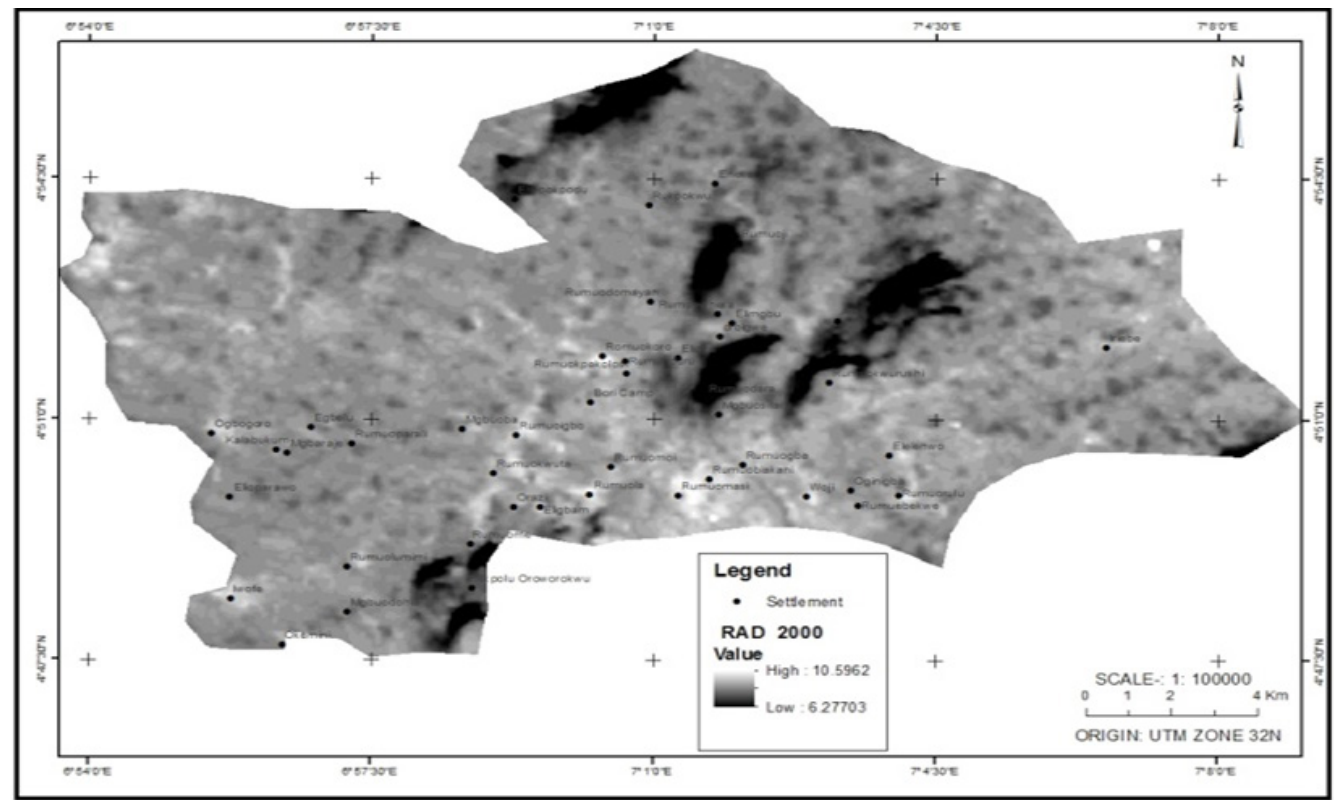

Figure 4 Radiance image sample.

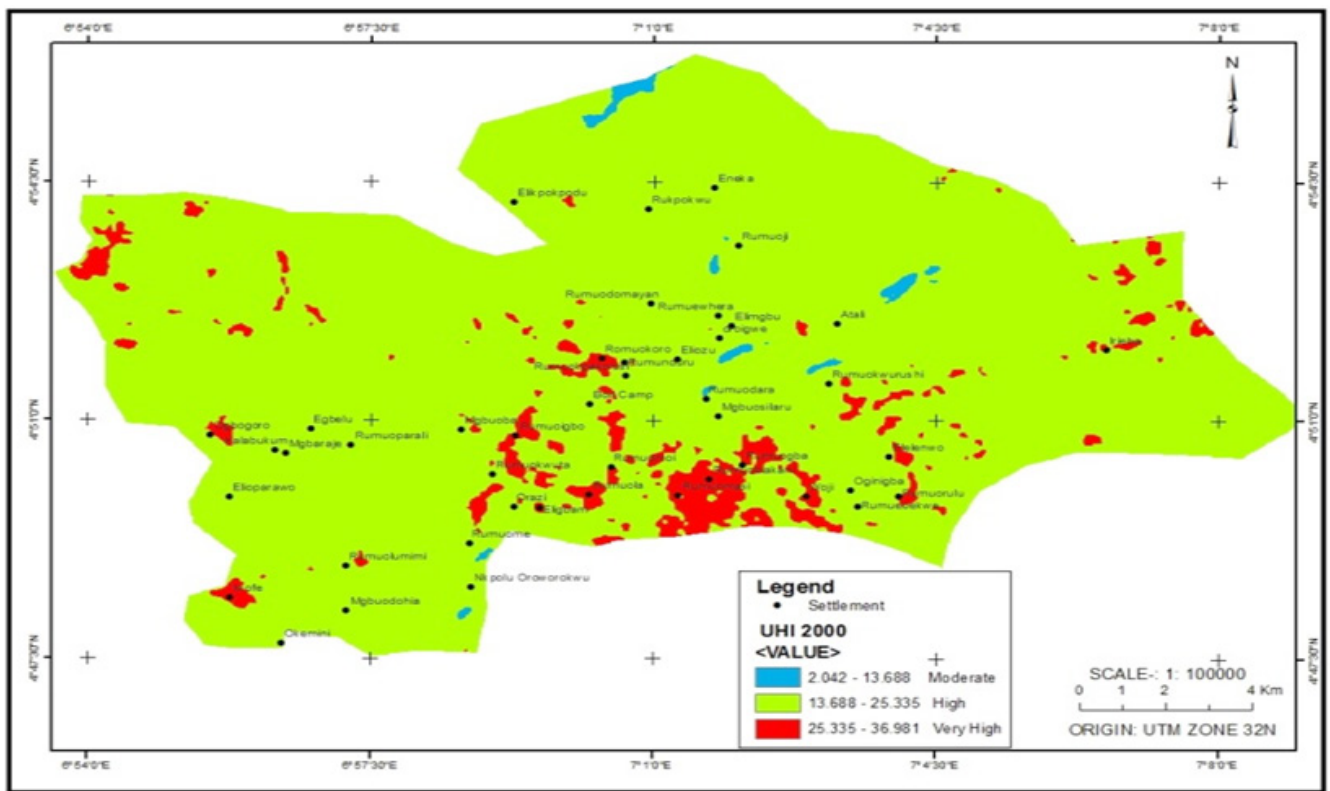

Figure 5 Temperature image sample.

\section{Results and discussion}

Table 3 shows the Mean temperature of the study area in five Epochs- 2000, 2005, 2010, 2015, and 2020. These temperature data were captured at 30 meters' grid across various Land use and Land cover LU/LC in the study area. Table 3 conform to the mean average LST of. ${ }^{9}$

As stated by ${ }^{9}$, the mean temperature of Port Harcourt city and its environs ranges between $30.0^{\circ} \mathrm{C}-33.0^{\circ} \mathrm{C}$. Obio/Akpor is one of the local government areas that makes up Port Harcourt metropolis. Therefore, the temperature data obtained is within the range of NIMET.

Table 4 shows the Geospatial attribute of the study area with its corresponding UHI in different years under investigation. The coordinates are referenced to the UTM projection system (datum WGS84, zone $32 \mathrm{~N}$ ). The coordinates were extracted from the thermal image of the study area Figure 6. 
Table 3 Showing the Results of the Urban Surface Temperature at different Epochs

\begin{tabular}{lll}
\hline SN & TEMP DATE & MEAN. $\left({ }^{\circ} \mathrm{C}\right)$ \\
\hline 1 & $07-01-2000$ & 23.48 \\
2 & $17-12-2005$ & 27.647 \\
3 & $03-01-2010$ & 31.598 \\
4 & $27-12-2015$ & 33.054 \\
5 & $31-01-2020$ & 33.07 \\
\hline
\end{tabular}

Table 4 Epoch Based Geospatial attributes of some settlement in the study area with their corresponding average Urban Heat Island (UHI)

\begin{tabular}{|c|c|c|c|c|c|c|c|}
\hline $\mathbf{S} / \mathbf{N}$ & SETTLEMENTS & EASTINGS (m) & NORTHINGS (m) & $\begin{array}{l}\mathrm{UHI}\left({ }^{\circ} \mathrm{C}\right) \\
2000\end{array}$ & $\begin{array}{l}\mathrm{UHI}\left({ }^{\circ} \mathrm{C}\right) \\
2005\end{array}$ & $\begin{array}{l}\mathrm{UHI}\left({ }^{\circ} \mathrm{C}\right) \\
2010\end{array}$ & $\begin{array}{l}\mathrm{UHI}\left({ }^{\circ} \mathrm{C}\right) \\
2015\end{array}$ \\
\hline I & OGBOGORO & 270307 & 535900.4 & 23.83 & 26.68 & 30.81 & 32.32 \\
\hline 2 & $\mathrm{CHOBA}$ & 268085.4 & 538632.7 & 24.26 & 27.13 & 31.15 & 33.37 \\
\hline 3 & RUMUOLOGU & 268987.1 & 539191.9 & 24.26 & 27.73 & 31.42 & 33.89 \\
\hline 5 & RUMUEKINI & $27|7| 5.7$ & 540555.7 & 24.26 & 28.28 & 31.97 & 34.41 \\
\hline 6 & RUMU-OPARALA & 272549 & 536292.9 & 24.26 & 28.16 & 32.13 & 33.37 \\
\hline 7 & MGBUOBA & 274789.7 & 535574.9 & 23.83 & 28.1 & 32.06 & 33.37 \\
\hline 8 & WOJı & $2846 \mid 4.5$ & 533999.7 & 23.83 & 28.14 & 31.98 & 33.37 \\
\hline 9 & RUMUODARA & 281772.9 & 537883.5 & 23.4 & 28.14 & 31.95 & 33.89 \\
\hline 10 & RUKPOKWU & 278375.1 & 542343.7 & 23.4 & 28.01 & 31.88 & 33.89 \\
\hline 11 & ELIOPARAWO & 274224.4 & 534596.9 & 23.4 & 27.75 & 31.75 & 33.89 \\
\hline 12 & EGBELU & 275777.8 & 539063 & 20.77 & 25.72 & 29.66 & 31.26 \\
\hline 13 & IWOFE & 270934.4 & 531867.1 & 21.21 & 25.84 & 29.71 & 31.26 \\
\hline 14 & OKEMINI & 272122.8 & 531064.4 & 21.65 & 25.92 & 29.71 & 31.79 \\
\hline 15 & MGBUODOHIA & 274742.5 & 530001.8 & 22.09 & 26 & 29.66 & 31.79 \\
\hline 16 & RUMUOLUMINI & 272386.1 & 532168.3 & 22.09 & 25.85 & 29.6 & 31.26 \\
\hline 17 & $\begin{array}{l}\text { NKPOLU } \\
\text { OROWOROKWU }\end{array}$ & 276854.1 & $53 \mid 821.1$ & 22.53 & 25.57 & 29.54 & 31.26 \\
\hline 19 & ELIGBAM & 277610.8 & 534334 & 22.97 & 25.83 & 29.41 & 31.26 \\
\hline 20 & ORAZI & 277169.3 & 534483.7 & 23.4 & 26.17 & 29.64 & 31.79 \\
\hline 21 & RUMUOKWUTA & 277313.6 & 535367.7 & 23.83 & 26.54 & 30.35 & 32.32 \\
\hline 22 & RUMUOIGBO & 277478.6 & 536934 & 23.83 & 26.9 & 31.06 & 32.84 \\
\hline 23 & RUMUOLA & 281088 & 534760.6 & 24.26 & 27.36 & 31.42 & 33.89 \\
\hline 24 & RUMOIMOI & 278502.3 & 535367.2 & 24.26 & 27.9 & 31.67 & 35.44 \\
\hline 25 & RUMUOMASI & 281028.9 & 534058.2 & 24.26 & 28.33 & 31.88 & 35.44 \\
\hline 26 & RUMUOGBA & $28268 I .4$ & 535595.1 & 24.26 & 28.39 & 32.05 & 34.92 \\
\hline 27 & OGINIGBA & 282521.9 & 533984.7 & 24.26 & 28.17 & 32.1 & 33.89 \\
\hline
\end{tabular}


Table 4 Shows the Geospatial attribute of the study area with its corresponding UHI in different years under investigation

\begin{tabular}{llllllll}
\hline $\mathbf{2 8}$ & RUMUEBEKWE & $\mathbf{2 8 4 6 1 9 . 4}$ & $\mathbf{5 3 5 7 0 7 . 3}$ & $\mathbf{2 3 . 8 3}$ & $\mathbf{2 7 . 9 8}$ & $\mathbf{3 2 . 0 4}$ & $\mathbf{3 2 . 8 4}$ \\
\hline 29 & ELELENWO & 286259.5 & 535256 & 23.83 & 28.02 & 32.01 & 32.84 \\
30 & RUMUOKWURUSI & 284176 & 536992.4 & 23.4 & 28.22 & 32.1 & 33.37 \\
31 & OROIGWE & 282838.2 & 539151.1 & 23.4 & 28.35 & 32.25 & 33.89 \\
32 & ATALI & 284032.5 & 538564.6 & 23.4 & 28.25 & 32.29 & 34.41 \\
33 & RUMUEWHERA & 282105.7 & 541047.4 & 23.4 & 27.99 & 32.19 & 33.89 \\
34 & RUMUODOMAYA & 278059.4 & 539783.3 & 23.4 & 27.54 & 31.99 & 33.37 \\
35 & RUMUOJI & 282180.8 & 539351.4 & 19.88 & 25.33 & 28.95 & 31.26 \\
36 & ENEKA & 281373 & 541522.1 & 20.77 & 25.41 & 29.16 & 31.26 \\
37 & ELIKPOKPODU & 277486.3 & 542696.4 & 21.21 & 25.5 & 29.25 & 31.69 \\
38 & RUMUOKORO/ & 276353.5 & 538249.6 & 21.65 & 25.59 & 29.25 & 31.65 \\
& ELIOZU & & & & & & \\
39 & BORI CAMP & 276997 & 537842.8 & 21.65 & 25.68 & 29.26 & 31.34 \\
40 & & 281795 & 538733.3 & 22.09 & 25.57 & 29.27 & 31.21 \\
\hline
\end{tabular}

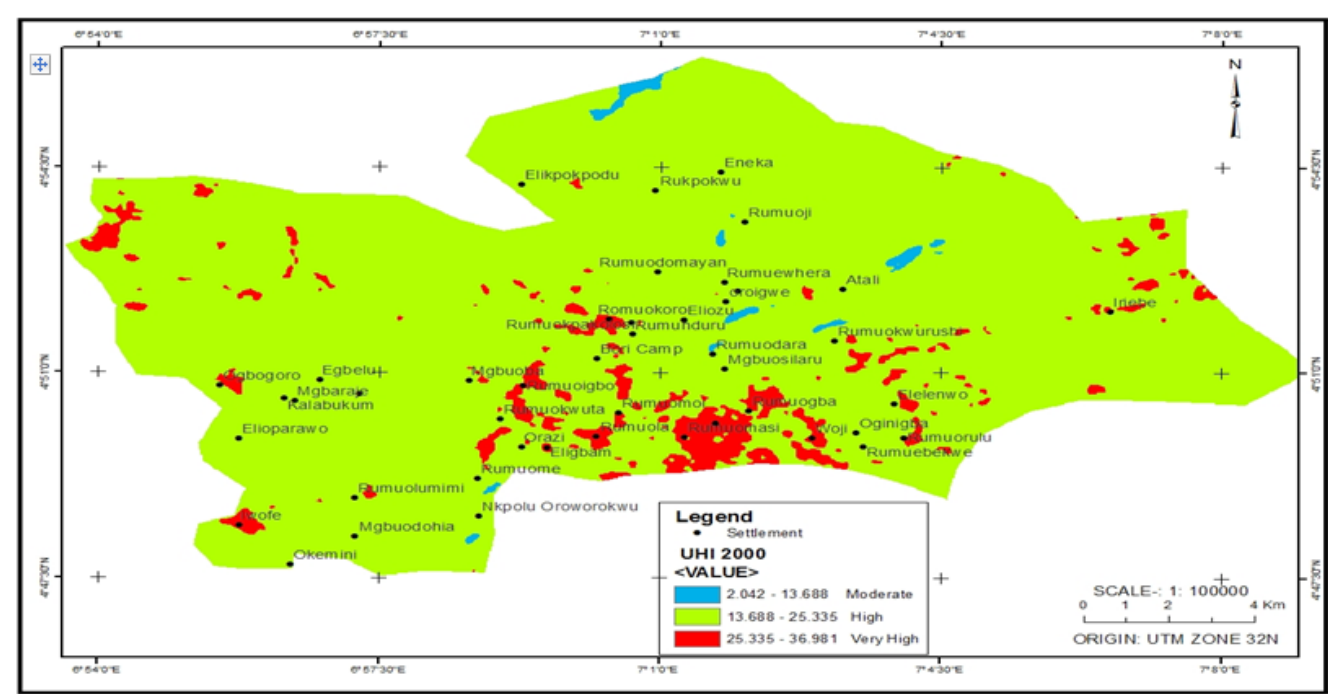

Figure 6 Showing the year 2000 Urban Surface Temperature of the study area.

Source: SPOT imagery.

The Urban Surface Temperature Varies from $2.042^{\circ} \mathrm{C}$ to $36.981^{\circ} \mathrm{C}$ with an average temperature of $23.480{ }^{\circ} \mathrm{C}$ across various Land use and Land cover (LU/LC) in the area. The moderate zone is between $2.042^{\circ} \mathrm{C}$ to $13.688^{\circ} \mathrm{C}$ which is the water body represented on the map with a 'blue colour' because of the low energy radiation. The high area varies from $13.688^{\circ} \mathrm{C}$ to $25.335^{\circ} \mathrm{C}$ which is a vegetative area represented on the map with a 'light green colour'. Area such as Eneka, Rumuokwu, Elikpokodu, Rumuoji, Rumuodomaya, Rumuewhera, Oroigwe, Atali, Rumuokoro/Eliozu, Rumuodara, Mgbuosilaru, Rumuokwurusi, Egbelu, Mgbaraie, Kalabukum, Elioparawo, Mgbuodohia, Rumuolumini, Iwofe and Ogbogoro falls under this zone. The very high zone varies between $25.335^{\circ} \mathrm{C}$ to $36.981^{\circ} \mathrm{C}$ which is the build-up area shown on the map as a 'red colour'. The built-up area consists of roads (paved and unpaved), commercial, residential, and industrial buildings. This area is inundated with higher temperature because of the high consideration of human activities. These areas include Rumuomasi, Woji, Rumuogba, Rumuola, Eligbam, Orazi,
Rumuokwuta and Rumuoigbo. From the analysis in 2000 , the higher temperature is at the central-southern part of the study area Figure 7.

The Urban Surface temperature varies from $22.917^{\circ} \mathrm{C}-32.105^{\circ} \mathrm{C}$ with an average temperature of $33.054^{\circ} \mathrm{C}$ across various Land use and Land cover LU/LC in the study area. The moderate zone is between $22.917^{\circ} \mathrm{C}-25.980^{\circ} \mathrm{C}$ which is the water body shown on the map as 'blue colour' Area in the zone includes Elioparawo, Okemini and Ogbogoro. The High zone varies between $25.980^{\circ} \mathrm{C}-29.043^{\circ} \mathrm{C}$ which is a Vegetative area shown on the map as a 'light green colour'. The settlements in this zone are Iwofe, Mgbuodohia, Egbelu, Mgbaraje, Rukpokwu, Eneka, Kalabukum, Rumuodomaya, Bori camp and Rumuodara. The very high zone varies between $29.043^{\circ} \mathrm{C}-32.105^{\circ} \mathrm{C}$ which is shown on the map as a 'red colour'. These settlements constitute high-temperature value because of human activities in the area. It consists of roads (paved and unpaved), commercial, residential, and industrial buildings. This zone is classified as the built-up area. 


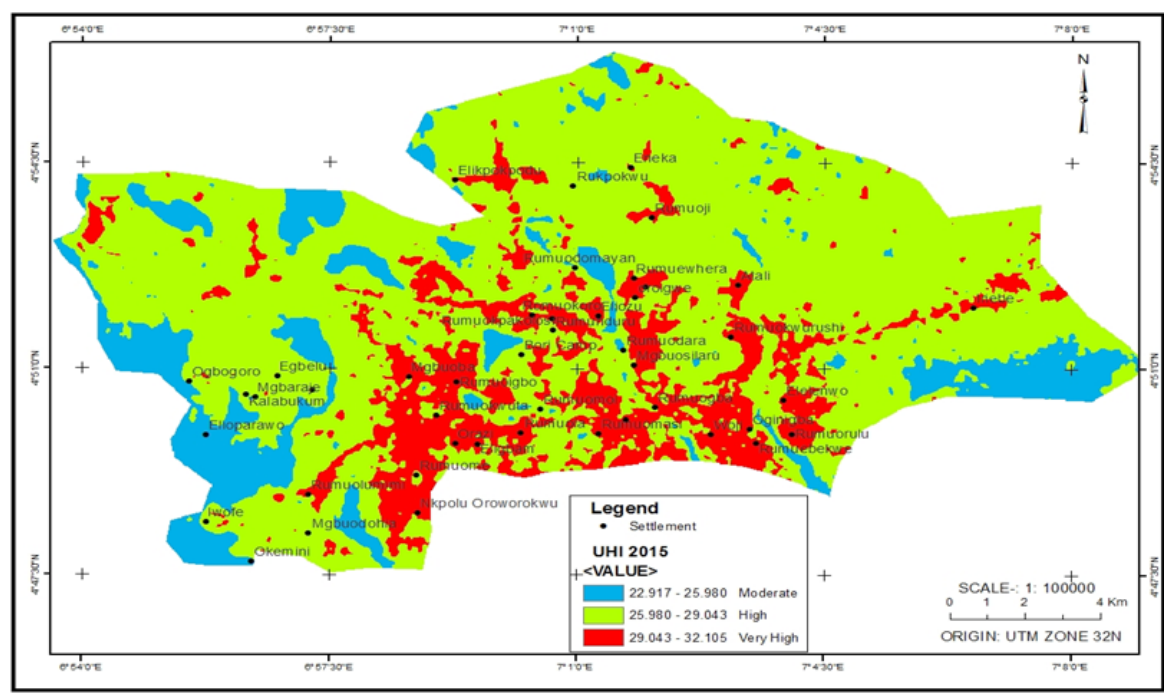

Figure 7 Shows the Urban Surface Temperature of the study area in the year 2015.

Source; SPOT imagery.

The settlements in the zone area; Rumuolumini, Nkpolu Oroworokwu, Rumuome, Orazi, Rumuokwuta, Mgbuoba, Rumuoigbo, Eligbam, Rumuola, Rumuomasi, Rumuogba, Rumuebekwe, Rumuorulu, Elelenwo, Rumuokwurushi, Rumunduru, Rumuokoro/ Eliozu. From the analysis in the 2015 map, the higher temperature zone increases from the centre of the study area to the fringes in a circular form in all directions. The results show an increasing trend of surface temperature observed at the central-southern part of the study area in 2000 has progressed towards the Northern, Eastern and Western Fringes in the study area in 2015 Figure 8.

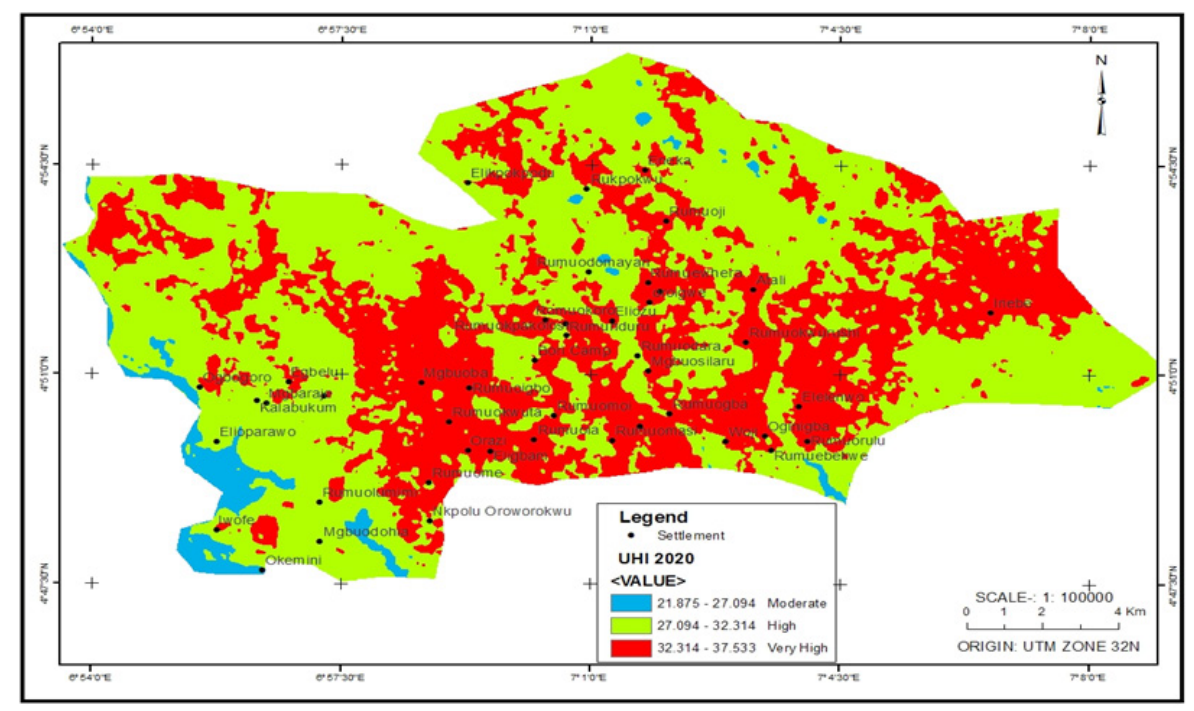

Figure 8 Shows the Urban Surface Temperature of the study area in 2020.

Source: SPOT imagery.

The temperature varies from $21.875^{\circ} \mathrm{C}$ to $37.533^{\circ} \mathrm{C}$ with an average temperature of $33.070^{\circ} \mathrm{C}$ across various $\mathrm{LU} / \mathrm{LC}$ in the study area. The moderate zone is between $21.875^{\circ} \mathrm{C}-27.094^{\circ} \mathrm{C}$ which is the water body represented on the map with a 'blue colour'. The High zone varies between $27.094^{\circ} \mathrm{C}-32.314^{\circ} \mathrm{C}$ which is a vegetative area represented on the map as a 'light green colour'. The settlements in this zone are Elioparawo, Mgbuodoha, Rumuolumini, Kalabukum. The very high zone varies between $32.314^{\circ} \mathrm{C}$ to $37.533^{\circ} \mathrm{C}$ which is represented on the map as 'red colour'. These settlements constitute high temperature value because of human activities in the area. It consists of roads (paved and unpaved), commercial, residential, and industrial buildings. This zone is classified as a built-up area.
The settlements in this zone area; Nkpolu Oroworokwu, Rumuome, Orazi, Rumuokwuta, Mgbuoba, Rumuoigbo, Eligbam, Rumuola, Rumuomasi, Rumuogba, Rumuebekwe, Rumuoigbo, Elelenwo, Rumuokwurushi, Rumunduru, Rumuokoro/Eliozu, Oroigwe, Rumuewhera, Atali, Iriebe, Oginigba, Woji, Bori camp, Rukpokwu, Eneka, Rumuoji, Elikpokpodu, Rumuorulu, Rumuebekwe. From the results in the 2020 map, the higher temperature zone increases from the centre of the study area to the fringes in all directions- East, West, North and South directions of the study area. There are compelling proof that the surge in temperature is a result of rapid and uncontrolled urbanisation. 
From the spatial distribution of very high temperature shown on the map, it is observed that there is an increase in surface temperature distribution across the local government from 2000 to 2020. From 2000 to 2020, it is observed that the urban surface temperature of the study area increased from the centre to the fringes in all directionsNorth, South, West, and East.

Figures 6, 7 and 8 conform to the study of ${ }^{24}$ where Remote Sensing and GIS techniques were applied by using LANDSAT Imageries to Analyse the urban surface temperature of the Penang Island.

The graphical representation of Urban Heat Island (UHI) of the study area from 2000 to 2020 . The graph indicates the trend in urban surface temperature variation of the study area from 2000 to 2020 Figure 9 .
In 2000 , the average urban temperature of the study area was $23.480^{\circ} \mathrm{C}$, the value increase to $27.647^{\circ} \mathrm{C}$ in 2005 with a difference of $4.167^{\circ} \mathrm{C}$. The temperature of 2005 increased to $31.598^{\circ} \mathrm{C}$ in 2010 with a difference in temperature of $3.951^{\circ} \mathrm{C}$. Accordingly, the temperature of 2010 increased to $33.054^{\circ} \mathrm{C}$ in 2015 with a temperature difference of $1.456^{\circ} \mathrm{C}$. However, the temperature of 2015 increased to $33.070^{\circ} \mathrm{C}$ with a difference of $0.016^{\circ} \mathrm{C}$. The analysis shows an increasing trend in the urban surface temperature of the study area in the various years under investigation. This result conformed to the study of ${ }^{25}$ in Port Harcourt Local Government Area, Rivers State, Nigeria on derivation of land surface temperature (LST) from LANDSAT 6 and 7 Imageries and its Relationship with two Vegetation Indices (Ndvi and Gndvi) where the increase of LST was noted in different epochs in their study area.

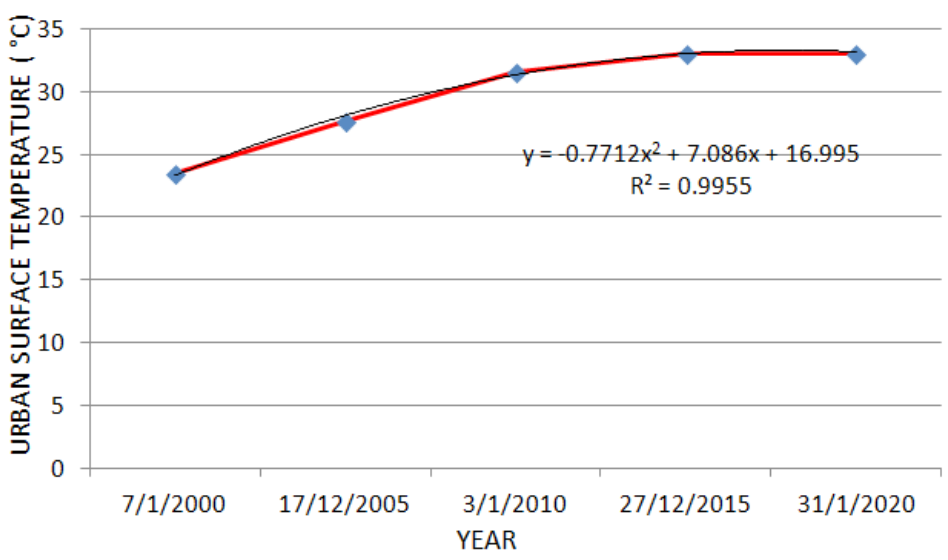

Figure 9 Graphical representation of Urban Surface Temperature vs. Year of the study area in 2000-2020.

In addition, the results indicate that there is a $40 \%$ increase in mean urban surface temperature between the years 2000 and 2020 . This result conforms to ${ }^{26}$ where RS and GIS approach was employed to quantify the trends in land surface temperature and urban heat island intensity in Mediterranean cities in view of smart urbanisation. The predictive quadratic model indicates that there is a strong positive correlation in urban surface temperature between the years 2000 to 2020 . This conforms to the study of ${ }^{27}$ where remote sensing techniques were used to examine the Correlation between factors of urbanisation and differences in land surface temperature (LST) in the subtropical climate of Pinellas County, Florida. And this model can be used to forecast Urban Surface Temperature within the study area.

\section{Planning implications of mapping urban heat islands}

There are some planning implications inherent in the identification and mapping out of Urban Heat Islands that have become significant components of urban planning in recent times. These are occasioned by the nexus between climate change and heat island formation in most urban centres. UHI formation has had very harmful impacts on the wellbeing and health of residents across all age cohorts from the elderly, infants, adults, and others within the vulnerability spectrum because it reduces the ability to function, live and interact comfortably. Implicitly, the existence of UHI spots has engendered changes in the planning and design of buildings and adjoining social infrastructure. ${ }^{28}$

For instance, the formation of Urban Heat Island has changed the dynamic of city planning, design, and implementation because UHI has posed considerable challenges to city managers and other built environment professionals. These challenges have lead all involved to seek alternative ways of redesigning and building sustainable and environmentally friendly cities with materials that reduce the impact of UHI on residents. Such environmentally friendly materials include the erection of vertical ecosystems that enables the creation of a microclimate that significantly lowers the temperature of the building envelope as it improves the energy efficiency of such buildings. ${ }^{29}$

Consideration is being given to the adaptive climatic design of the building envelope, design of shading devices and incorporation of passive cooling techniques that ensures protection from heat orientation of the building exposing the surfaces, and thermal comfort for occupants of the building. The built environment professionals have advocated for the use of dark coloured roofs, streets and the placement of pavements that absorb the solar energy and transmit them inside the buildings and contribute to the urban heat island effect. ${ }^{30}$ This is because the higher the reflective power and emissivity of a material, the less likely it is to store heat and radiate it back into the atmosphere or the building through the walls and roof. ${ }^{31,32}$

\section{Conclusion}

This study has shown that there is a phenomenal increase in Urban Surface Temperature in the Obio/Akpor Local Government Area of Rivers State. Remote Sensing and GIS techniques were adopted to monitor this urban phenomenon and model it to show the trend in its occurrence from the year 2000 to 2020 . Remotely sensed data has been used to derive surface temperature directly as it provides significant ways of monitoring the urban environment and human activities alike. Generally, the surface temperature is mainly affected by the type of land use engendered by urbanisation, depleting vegetation, and wetlands loss. The relationship between urban surface temperature and land cover types indicates that the best solution to reduce UHI is the adoption of effective urban planning strategies. Also, the acquisition of remote sensing data integrated into GIS 
becomes a powerful tool in planning and managing any research that involves spatial data analysis to develop an informed decision-support system for the government and individuals.

\section{Recommendations}

Based on the findings from the study, the following recommendations are made:

i. There should be a conscious move to reduce the continuous rural-urban migration by creating more urban centres in other local government areas in the State.

ii. The green belt policy should be encouraged with tree planting as the focus of mitigating the effect of air pollution, heatwaves and harmful gases emission into the environment.

iii. Policymakers and city managers should ensure effective control of unplanned urban expansion in already built-up and/ or undeveloped areas of the city.

iv. Built environment practitioners should encourage the use of albedo of materials.

v. Residents in Urban Heat Islands should develop the culture of reducing anthropogenic causes with the use of environmentally friendly and sustainable appliances.

vi. Property developers should be encouraged to install passive cooling systems in their properties and also tilt towards adapting a Climate Responsive Architecture.

\section{References}

1. EPA. Heat Island Impacts; 2019.

2. Surawar M, Kotharkar R. Assessment of Urban Heat Island through Remote Sensing in Nagpur Urban Area Using LANDSAT 7 ETM + Satellite Images. International Journal of Urban and Civil Engineering. 2017;11(7):868-874.

3. UN. $68 \%$ of the world population projected to live in urban areas by 2050 , says UN; 2018.

4. Favretto A. Urban Heat Island analysis with Remote Sensing and GIS methods: an application in the Trieste area (North-East of Italy ). Bollettino Della Società Geografica Italiana Serie. 2018;1(1):215-229.

5. Akbari H. Energy Saving Potentials and Air Quality Benefits of Urban Heat Island Mitigation. United States; 2005.

6. Rinkesh. What is Urban Heat Island?; 2019.

7. Patrick E, Phelan KK, Mark M, et al. Urban Heat Island; Mechanisms, Implications, and Possible Remedies. Annual Review of Environment and Resources. 2015;40:285-307.

8. Nigerian Population Commission (NPC). Nigerian Population Projection Bullettin 2006; 2006.

9. Nigerian Meteorological Agency (NIMET). Nigeria Climate Review Bulletin; 2011. 1-40 p.

10. Farina A. Exploring the relationship between land surface temperature and vegetation abundance for urban heat island mitigation in Seville, Spain. Master. Lund University; 2012.

11. Li L, Zha Y, Wang R. Relationship of surface urban heat island with air temperature and precipitation in global large cities. Ecological Indicators. 2020;117:106683.

12. Zipper SC, Schatz J, Singh A, et al. Urban heat island impacts on plant phenology: intra-urban variability and response to land cover. Environ Res Lett. 2016;11:054023.
13. Urban A, Davidkovova H, Kysely J. Heat and cold-stress effects on cardiovascular mortality and morbidity among urban and rural populations in Czech Republic. Int J Biometeorol. 2014;58(6):1057-1068.

14. Rasul AO. Remote Sensing of Surface Urban Cool and Heat Island Dynamics in Erbil, Iraq, between 1992 and 2013. Department of Geography, University of New Leicester; 2016.

15. Johnson DP, Wilson JS, Luber GC. Socioeconomic indicators of heatrelated health risk supplemented with remotely sensed data. International Journal of Health Geographics Int J Health Geogr. 2009;8(1):57.

16. Zhao L, Lee X, Smith RB, et al. 'Strong contributions of local background climate to urban heat islands'. Nature. 2014;511(7508):216-219.

17. Bonan GB. Ecological climatology: concepts and applications. Cambridge: Cambridge University Press. 2002.

18. Celestian SB, Martin CA. 'Rhizosphere, surface, and air temperature patterns at parking lots in Phoenix, Arizona, US'. Journal of Arboriculture. 2004;30(4):245-252.

19. Lee JS, Kim JT, Lee MG. 'Mitigation of urban heat island effect and greenroofs', Indoor and Built Environment. 2014;23(1)62-69.

20. Tarle M. Application of GIS in Defining Urban Heat Island Using Transect Data: Urban Heat Island Using GIS Mapping. Saarbrücken, Germany: Lambert Academic Publishing. 2010.

21. Su Y, Foody GM, Cheng K. 'Spatial non-stationarity in the relationships between land cover and surface temperature in an urban heat island and its impacts on thermally sensitive populations'. Landscape and Urban Planning. 2012;107(2):172-180.

22. Golden JS, Brazel A, Salmond J. 'Energy and water sustainability: The role of urban climate change from metropolitan infrastructure'. Journal of Engineering for Sustainable Community Development. 2006;1(1):55-70.

23. Elachi $\mathrm{C}$, Van $\mathrm{Zyl} \mathrm{J}$. Introduction to the physics and techniques of remote sensing. Second edn. Hoboken, NJ, USA: John Wiley \& Sons. 2006.

24. Nor Aizam Adnan, Nur Fatin Fakhira Noralam, Siti Aekbal Salleh. Applied Remote Sensing and Geospatial Research Group Faculty of Architecture. Planning and Surveying University Technology MARA 40450 Shah Alam, Selangor, Malaysia.

25. Richard JU, Ibochi Andrew Abah. "Derivation of Land Surface Temperature (LST) from LANDSAT 7 \& 8 Imageries and its Relationship with two Vegetation Indices (NDVI and GNDVI)." International Journal of Research - Granthaalayah. 2019;7(2):108-120.

26. Anastasios Polydoros, Mavrakou, Thaleia, et al. "Quantifying the Trends in Land Surface Temperature and Surface Urban Heat Island Intensity in Mediterranean Cities in View of Smart Urbanization". Urban Sci. 2018;2(1):16.

27. Bruce Mitchell Coffyn. "Urbanization and Land Surface Temperature in Pinellas County. Florida" Graduate Theses and Dissertaions./3250. University of South Florida. 2011.

28. Gorse C, Parker J, Thomas F. The Planning and Design of Buildings: Urban Heat Islands-Mitigation. In Industry4.0 and Engineering for a sustainable Future, Springer, Cham. 2019;211-225.

29. Kingsbury N, Dunnett N. Planting green roofs and living walls. $2^{\text {nd }}$ Ed., Timber Press [22]. Liu, K., Bass, B., 2005, Performance of green roof systems, Ottawa: National Research Council Canada. 2008.

30. Akbari H, Menon S, Rosenfeld A. Global cooling: increasing solar reflectance of urban areas to offset $\mathrm{CO}_{2}$. In press, Climatic Change. 2008.

31. Paroli RM, Gallagher JF. Fact or fiction - clarifying the myths and realities of green roofs, white roofs and high-performance roofs, Canadian Property Management: B.C./Alberta Edition. 2018;16(1).

32. Synnefa A, Santamouris M, Apostolakis K. On the development, optical properties and thermal performance of cool colored coatings for the urban environment, Solar Energy. 2007;81(4):488-497. 